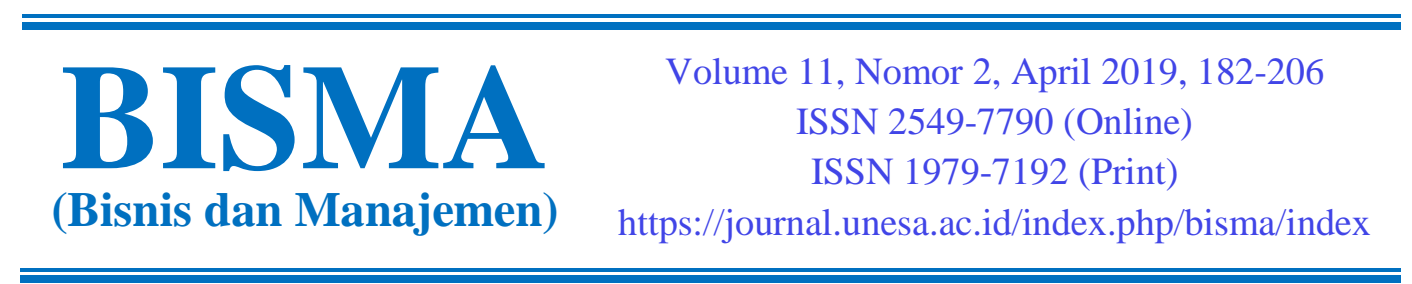

\title{
Peran Lembaga Simpan Pinjam Berbasis Masyarakat (LSPBM) Usaha Bersama Desa Siboang terhadap Pembangunan Ekonomi Pedesaan
}

\author{
Nirmala Dewi ${ }^{1}$, Moh. Arafa ${ }^{2}$, Rika Suprapty ${ }^{3}$ \\ STIE Panca Bhakti Palu ${ }^{1,2,3}$ \\ Email Korespondensi: rikasu.hidar@gmail.com
}

\begin{abstract}
The purpose of this research is investigating and analyzing the basic needs of CommunityBased Savings and Loan Institutions as well as efforts in local economic development and determining the strategies needed in developing the capacity of Community-Based Savings and Loan Institutions (LSPBM) and Small and Medium Enterprises (SME) in Siboang Village, Sojol Sub-District, Donggala District. This study applies a qualitative approach supported by the study of quantitative data. The data collected consists of primary data and secondary data. Primary data was collected by in-depth interviews with key figures and the researcher conducted observations, while secondary data were obtained from various literature studies. The technique of analyzing primary data and secondary data is processed through three stages of activity and carried out simultaneously, namely data reduction, data presentation and drawing conclusions through verification. Furthermore, qualitative data is processed into quantitative data, the researcher applies the SWOT analysis method that deals with internal and external factors of qualitative research that will produce a development strategy for the Joint Venture LSPBM. The results show that the role of LSPBM is quite large in encouraging the local economy and is able to provide loans to LSPBM members in order to increase business, and it can develop and strengthen Joint Ventures LSPBM with SMEs in business and sharing cooperation for service and service coverage.
\end{abstract}

Keywords: cooperation; loan; rural economic development; SMEs; SWOT

Received: 4 Januari 2019 Reviewed: 18 Januari 2019

Accepted: 2 April 2019

Published: 30 April 2019

\section{PENDAHULUAN}

Salah satu lembaga keuangan yang dapat dimanfaatkan dan didorong untuk membiayai kegiatan perekonomian di pedesaan yang mayoritas usaha penduduknya masuk dalam segmen mikro adalah Lembaga Simpan Pinjam Berbasis Masyarakat (LSPBM). Secara sederhana, LSPBM dapat diartikan sebagai suatu lembaga jasa 
layanan keuangan tabungan dan kredit (simpan-pinjam) dalam skala mikro dan kecil yang berkelanjutan bagi masyarakat yang mempunyai usaha skala mikro dan kecil. Bentuk-bentuk dari LSPBM ini beraneka ragam, bisa berbentuk rentenir sampai berbentuk koperasi simpan pinjam.

Keberadaan LSPBM tidak terlepas dari perkembangan Usaha Mikro, Kecil, dan Menengah (UMKM). UMKM merupakan indikator berjalannya roda perekonomian di suatu desa, mengingat populasi UMKM pada tahun 2015 di Indonesia mencapai 57,9 juta, di mana pelaku UMKM diperkirakan akan terus bertambah. Selama ini UMKM telah memberi kontribusi pada PBD sebesar 58,92\% dan penyerapan tenaga kerja sebanyak 97,30\% (Kristi, 2009). Hal serupa terjadi di Desa Siboang, Kecamatan Sojol, Kabupaten Donggala, Provinsi Sulawesi Tengah. UMKM di Desa Siboang dikelompokkan bergerak di bidang produksi sebanyak 84, dagang sebanyak 53 sementara untuk kelompok pengolahan dan usaha jasa tidak ada. UMKM-UMKM ini didukung oleh Lembaga Simpan Pinjam sebagai LSPBM yang memberikan bantuan modal berupa uang.

Dalam perkembangannya, lembaga-lembaga keuangan mikro ini lebih mengena di kalangan pelaku UMKM karena sifatnya yang lebih fleksibel, misalnya dalam hal persyaratan dan jumlah pinjaman yang tidak seketat persyaratan perbankan maupun keluwesan pada pencairan kredit. Hal ini merupakan salah satu indikator bahwa keberadaan lembaga-lembaga keuangan mikro sesuai dengan kebutuhan pelaku UMKM, yang umumnya membutuhkan pembiayaan sesuai skala dan sifat usaha kecil. Mengingat pentingnya ranah ekonomi yang merupakan titik sentral dalam kehidupan masyarakat pedesaan, maka dalam pembangunan ekonomi di Desa Siboang diperlukan upaya untuk merevitalisasi kelembagaan khususnya di bidang ekonomi untuk bisa memaksimalkan sumberdaya yang ada di masyarakat pedesaan dalam memenuhi kebutuhan hidupnya. LSPBM dalam kegiatannya termasuk dalam kelompok LSPBM hanya pada saat pencanangan program PMPD diberikan nama yang mengidentikkan kelembagaan masyarakat sehingga dalam pengoperasian LSPBM murni dibentuk oleh masyarakat tanpa intervensi dari Pemerintah, hal ini dimaksudkan agar rasa kepemilikan lembaga tersebut tinggi sehingga ada keinginan masyarakat untuk keberlanjutan lembaga sebagai wadah bersama.

LSPBM adalah suatu kelembangaan yang dibentuk awalnya oleh Program Pemerintah yang dikenal dengan Program Pembedayaan Masyarakat untuk Pembangunan Desa (PMPD) yang dimulai sejak tahun 2003-2007 melalui Departemen Dalam Negeri pada Ditjen Pembedayaan Masyarakat Desa. Program ini di danai oleh Asian Development Bank (ADB). Khusus untuk pembentukkan kelembagaan LSPBM adalah bertujuan untuk peningkatan ekonomi masyarakat dalam kegiatan simpan pinjam. Keberadaan LSPBM usaha bersama desa Siboang 
sampai dengan RAT Tahun 2016 telah berjalan selama 12 tahun telah memiliki anggota berjumlah 703 anggota yang tersebar di desa Siboang bahkan desa-desa sekitar di wilayah kecamatan Sojol. Dalam kegiatan simpan pinjam sudah mendanai kelompok usaha berupa: kelompok usaha produksi, kelompok dagang dengan jumlah kredit kelompok perdagangan sebanyak Rp10.177.250.000,00 dan kelompok produksi jumlah kredit sebanyak Rp7.826.150.000,00. Jumlah perputaran modal sendiri mencapai $42,68 \%$ yang berarti sangat ideal dalam upaya menumbuhkan berbagai sektor ekonomi desa yang terus maju dan berkembang. Rata-rata setiap kelompok usaha sudah mendapatkan 3-5 kali kredit bergulir yang berarti kemampuan lembaga tersebut sudah beroperasi dengan baik. Tingkat kecukupan modal (CAR) dari laporan keuangan yang ada pada laporan akhir tahun 2016 adalah sebesar $30,30 \%$ dengan jumlah total aktiva LSPBM tahun 2016 adalah sebesar Rp1.426.336.390,00.

Adapun gambaran bahwa LSPBM telah memberikan kredit kepada anggota yang telah dicairkan sejak pembentukkan bernilai Rp18.003.400.000,00 dengan plafon nilai sampai dengan 50 juta kepada anggota. Kegiatan simpan pinjam berjalan lancar walaupun masih terdapat kredit macet sebesar Rp516.233.850,00 dan dana simpanan sebesar Rp772.730.000,00 di rekening bank yang tidak dapat diputar menginggat pengurus LSPBM mempertimbangkan resiko kredit. Yang menjadi masalah dalam hal ini mengapa masih ada dana yang mengendap dan tidak disalurkan kepada anggota LSPBM, sedangkan jumlah perputaran modal sendiri mencapai $42,68 \%$ yang berarti masuk dalam kategori sangat ideal dan kecukupan modal CAR (Current Assets Rasio) sebesar 30,30\% yang artinya apabila terjadi likuidasi sudah bisa menutupi utang sebesar 30,30\%.

Penelitian ini bertujuan untuk mengaji dan menganalisis apa yang menjadi kebutuhan dasar bagi LSPBM di Desa Siboang; menganalisis peranan LSPBM dalam mengembangkan ekonomi lokal di Desa Siboang; dan menentukan strategi yang diperlukan dalam rangka mengembangkan kapasitas LSPBM maupun UMKM.

\section{Pembangunan Pedesaan dan Kelembagaan Finansial}

Menurut Syahyuti (2008) peran kelembagaan dalam pembangunan pedesaan merupakan pintu masuk agar suatu lembaga dapat berdiri dan diterima, khususnya di dalam aspek ekonomi. Revitalisasi kelembagaan ekonomi dinilai penting, agar kelembagan ini bisa kembali terlegitimasi dalam setiap individu yang berada di dalamnya dan bisa menumbuhkan rasa memiliki (sense of belonging), jika rasa memiliki ini sudah muncul, setiap individu akan berpartisipasi dan kelembagaan ini akan berkembang sehingga potensial untuk bisa mensejahterakan masyarakat karena 
di dalamnya sudah ada pembagian peran dan tanggung jawab dalam memenuhi kebutuhan ekonomi mereka.

Berdasarkan perkembangan pembangunan pedesaan yang terjadi selama beberapa dekade ini, terlihat bahwa fase-fase tersebut mengidentifikasikan proses komersialisasi pedesaan. Maka itu diperlukan upaya agar penduduk pedesaan bisa lepas dari komersialisasi ini, yaitu dengan cara menguatkan sistem produksi dan pengolahan yang berbasis tradisional sehingga masyarakat pedesaan tidak melulu ada dalam posisi subordinat. Persoalan ini sebenarnya dapat diatasi dengan adanya modal yang berputar di dalam sistem produksi dan pengolahan. Namun sayangnya keterbatasan modal merupakan persoalan paling rumit di wilayah pedesaan. Keterbatasan modal menyebabkan aktivitas ekonomi tidak berjalan, tidak berjalannya aktivitas ekonomi menyebabkan masyarakat berada dalam posisi subordinat tadi (Ellis dan Biggs, 2001). Berbekal dari situasi ini, sudah seyogyanya para perumus kebijakan pembangunan pedesaan mengawinkan kelembagaan sektor finansial dengan kebijakan pemerintah agar mampu menggerakkan kegiatan ekonomi di wilayah pedesaan, khususnya usaha mikro.

Yustika (2008) melihat secara umum persoalan lembaga keuangan di perdesaan dapat didentifikasikan menjadi tiga aspek berikut: (1) masalah akses kredit, (2) posisi tawar dan informasi masyarakat perdesaan yang sangat rendah menyebabkan rawan terhadap praktik manipulasi dari lembaga keuangan formal maupun semi-formal, dan (3) informasi yang asimetris (asymmetric information) dari pemberi pinjaman/kredit terhadap peminjam (borrower).

Pada umumnya, lembaga keuangan di pedesaan dibedakan dalam tiga jenis: (1) lembaga keuangan formal; (2) lembaga keuangan semi-formal; (3) lembaga keuangan mikro. Lembaga keuangan dikatakan formal jika lembaga tersebut secara operasional diatur dalam Undang-Undang perbankan dan disupervisi oleh bank sentral. Sedangkan lembaga keuangan semi-formal adalah lembaga keuangan yang tidak diatur dalam UU, tetapi disupervisi dan diregulasi oleh agen pemerintah maupun bank sentral. LKM beroperasi di luar regulasi dan supervisi lembaga pemerintah. LKM bukan sekedar menyediakan uang (cash) untuk keperluan transaksi, tetapi kadang-kadang menyediakan pinjaman dalam bentuk barang (in-kind) (Yustika, 2008). Karakter yang fleksibel, membuat LSPBM memiliki daya tahan yang kuat untuk hidup di wilayah pedesaan, karena LSPBM ini bersifat sangat fleksibel dalam artian memiliki hubungan personal antara kreditor dan debitor dan persyaratan administrasi yang dibutuhkan sangat sederhana. Kontrak maupun persyaratan sejumlah agunan tidak seperti pada lembaga keuangan formal. Dengan segala kemudahan inilah lembaga keuangan mikro sangat diterima di kalangan perdesaan. 
Nirmala Dewi, Moh. Arafa, Rika Suprapty Peran Lembaga Simpan Pinjam Berbasis Masyarakat (LSPBM) Usaha Bersama Desa Siboang terhadap Pembangunan Ekonomi Pedesaan

\section{Eksistensi Usaha Mikro, Kecil, dan Menengah}

Beberapa lembaga atau instansi bahkan UU memberikan definisi Usaha Mikro, Kecil,dan Menengah (UMKM), yang berbeda-beda antara satu dengan yang lainnya. Menurut Kementrian Menteri Negara Koperasi dan Usaha Mikro, Kecil, dan Menengah (Menegkop dan UMKM), bahwa yang dimaksud dengan Usaha Kecil (UK), termasuk Usaha Mikro (UMI), adalah entitas usaha yang mempunyai memiliki kekayaan bersih paling banyak Rp200.000.000, tidak termasuk tanah dan bangunan tempat usaha, dan memiliki penjualan tahunan paling banyak Rp1.000.000.000. Badan Pusat Statistik (BPS) memberikan definisi UMKM berdasarkan kunatitas tenaga kerja. Usaha kecil merupakan entitas usaha yang memiliki jumlah tenaga kerja 5 s.d 19 orang, sedangkan usaha menengah merupakan entitias usaha yang memiliki tenaga kerja 20 s.d. 99 orang. Pada 4 Juli 2008 telah ditetapkan Undang-undang No. 20 Tahun 2008 tentang Usaha Mikro, Kecil, dan Menengah. Definisi UMKM yang disampaikan oleh Undang-undang ini juga berbeda dengan definisi di atas. Menurut UU No 20 Tahun 2008 ini, yang disebut dengan Usaha Kecil adalah entitas yang memiliki kriteria sebagai berikut: (1) kekayaan bersih lebih dari Rp50.000.000,00 sampai dengan paling banyak Rp500.000.000,00 tidak termasuk tanah dan bangunan tempat usaha; dan (2) memiliki hasil penjualan tahunan lebih dari Rp300.000.000,00 sampai dengan paling banyak Rp2.500.000.000,00, dengan tidak mengenyampingkan berbagai definisi tersebut keberadaan pengusaha mikro, kecil dan menengah, khususnya yang berskala usaha mikro merupakan wujud kehidupan ekonomi sebagian besar rakyat Indonesia yang berada di bawah garis kemiskinan (Rahmada, 2008).

Kristi (2009) menyatakan bahwa proses pengembangan usaha mikro sebagai manifestasi perkembangan ekonomi lokal dan penganggulangan kemiskinan menjadi sangat penting sehubungan dengan pelaksanaan otonomi daerah. Proses ini tidak akan berjalan dengan baik kalau penguatan peran usaha mikro di tingkat lokal tidak diikut sertakan sebagai pihak berkepentingan utama. Di samping itu, penguatan peran pengusaha mikro tersebut mempunyai arti strategis bagi kesejahteraan masyarakat setempat, sekaligus sebagai penggerak perekonomian daerah dan transformasi sosial ekonomi dalam komunitas lokal. UMKM merupakan salah satu solusi untuk tetap bertahan dalam menghadapi krisis yakni dengan melibatkan diri dalam aktivitas usaha kecil terutama yang berkarakteristik informal. Pemberdayaan UMKM dinilai menjadi sangat strategis karena potensinya yang besar dalam menggerakkan kegiatan ekonomi masyarakat, dan sekaligus menjadi tumpuan sumber pendapatan sebagian besar masyarakat dalam meningkatkan kesejahteraannya. 


\section{Lembaga Keuangan Mikro/ Lembaga Simpan Pinjam Berbasis Masyarakat}

Lembaga Keuangan Mikro (LKM) di Indonesia menurut Bank Pembangunan Asia dan Bank Dunia (Gunawan, 2015) memiliki ciri utama, yaitu: (1) menyediakan beragam jenis pelayanan keuangan yang relevan atau sesuai dengan kebutuhan riil masyarakat, (2) melayani kelompok masyarakat yang berpenghasilan rendah, dan (3) menggunakan prosedur dan mekanisme yang kontekstual dan fleksibel agar lebih mudah dijangkau oleh masyarakat miskin yang membutuhkan.

Arif (2014) menyatakan bahwa lembaga keuangan mikro memiliki kelebihan yang paling nyata, yaitu prosedurnya yang sederhana, tanpa agunan, hubungannya yang cair (personal relationship), dan waktu pengembalian kredit yang fleksibel (negotiable repayment). Karakteristik itu sangat sesuai dengan ciri pelaku ekonomi di perdesaan (khususnya di sektor pertanian) yang memiliki asset terbatas, tingkat pendidikan rendah dan siklus pendapatan yang tidak teratur (bergantung panen). Karakter perdesaaan seperti itulah yang ditangkap dengan baik oleh pelaku lembaga keuangan mikro, sehingga eksistensinya mudah diterima oleh masyarakat kecil. Tetapi kelemahan utama dari lembaga keuangan mikro, yakni tingkat bunga kredit yang sangat tinggi, harus diperbaiki sebab keberadaannya cenderung eksploitatif kepada masyarakat miskin. Pemerintah dapat mendesain regulasi dengan jalan membatasi tingkat suku bunga, atau memperluas akses masyarakat miskin kepada kredit formal sehingga dalam jangka panjang tingkat bunga lembaga keuangan mikro akan tertekan. Model inilah yang harus diadopsi agar kepentingan masyarakat kecil tidak dirugikan (Arif, 2014).

\section{Kaitan Lembaga Keuangan Mikro dan Ekonomi Pedesaan}

Hermawan dan Andrianyta (2012) menyatakan bahwa kehadiran LKM dibutuhkan dalam perekonomian pedesaan paling tidak karena dua hal (Pantoro, 2010). Pertama, sebagai salah satu instrumen dalam rangka mengatasi kemiskinan. Masyarakat miskin pada umumnya mempunyai usaha skala mikro. Dalam terminologi World Bank, mereka disebut sebagai economically active poor atau pengusaha mikro. Dalam konfigurasi perekonomian Indonesia, lebih dari 90\% unit usaha merupakan usaha skala mikro. Mengembangkan usaha skala mikro merupakan langkah strategis karena akan mewujudkan broad bases development atau development through equity. Mereka membutuhkan permodalan guna mengembangkan kapasitas usahanya. Dengan usaha yang meningkat (menjadi usaha skala kecil), secara efektif akan mengatasi kemiskinan yang diderita oleh mereka sendiri dan diharapkan dapat membantu masyarakat dalam kategori fakir miskin. Pada sisi lain, skim keuangan mikro sangat sesuai dengan kebutuhan masyarakat berpenghasilan rendah. Kedua, LKM dibutuhkan karena menjadi salah satu instrumen 
Nirmala Dewi, Moh. Arafa, Rika Suprapty Peran Lembaga Simpan Pinjam Berbasis Masyarakat (LSPBM) Usaha Bersama Desa Siboang terhadap Pembangunan Ekonomi Pedesaan

pengembangan pasar keuangan mikro. Secara pragmatis, pasar keuangan mikro merupakan aspek keuangan dari semua proses ekonomi di segmen mikro yang meliputi segala sesuatu yang menyangkut tabungan dan kredit usaha. Pada pemahaman ini dicantumkan kata tabungan dan kredit, guna menghindarkan pemahaman sempit seolah-olah di segmen mikro pelaku-pelaku usahanya hanya membutuhkan kredit, melupakan bahwa mereka mempunyai potensi menabung, dan/atau dapat diberdayakan mempunyai kemampuan menabung. Pendek kata, pada pasar keuangan mikro terdapat potensi besar dalam hal penawaran (tabungan) dan permintaan (kredit). Berdirinya LSPBM merupakan jawaban dari kurang pekanya lembaga keuangan formal dalam merangkul UMKM, sehingga peranannya bisa dibilang sebagai katup penyelamat dalam proses pembangunan ekonomi pedesaan.

\section{Analisis SWOT}

Analisis SWOT merupakan salah satu alat yang yang dapat digunakan dalam proses perencanaan strategis organisasi. Alat lain yang biasa digunakan untuk analisis strategi adalah analisis PEST, analisis Five Forces, dan analisis 3C (PerusahaanPelanggan-Pesaing) (Akiyoshi \& Komoda, 2005). Analisis SWOT diungggulkan karena karena kesederhanaannya dan terus digunakan sejak tahun 1960-an. Kesederhanaan analisis SWOT telah menghasilkan penggunaan yang berkelanjutan baik di lingkungan perusahaan maupun di lingkungan akademik (Ghazinoory, Abdi, \& Azadegan-Mehr, 2011) sejak dikembangkan pada 1960-an. Disisi lain, terkadang dalam praktiknya analisis SWOT dapat menyebabkan keputusan bisnis yang salah ([Coman dan Ronen, 2009], [Wilson dan Gilligan, 2005]).

Latar belakang untuk analisis SWOT berasal dari kebutuhan untuk mengetahui mengapa perencanaan perusahaan gagal (Panagiotou, 2003; Helms \& Nixon, 2010; Rostirolla \& Rostirolla, 2011). SWOT adalah singkatan dari kekuatan, kelemahan, peluang dan ancaman perusahaan. Menurut para pendukung SWOT, kekuatan mengacu pada kemampuan yang melekat untuk bersaing dan tumbuh kuat. Kelemahan adalah defisiensi bawaan yang melumpuhkan pertumbuhan dan kelangsungan hidup. Kekuatan dan kelemahan sebagian besar internal. Peluang adalah peluang bagus dan peluang yang tersedia untuk pertumbuhan. Ancaman adalah tantangan yang dimiliki secara eksternal, yang mungkin menekan kekuatan yang melekat, mempercepat kelemahan dan menahan peluang agar tidak meledak. Untuk berhasil di bidang apa pun, kelemahan harus diatasi melalui kekuatan dan ancaman harus ditransfer ke peluang.

\section{METODE PENELITIAN}

Penelitian ini menggunakan pendekatan kualitatif. Pendekatan ini dipilih karena dianggap mampu memberikan pemahaman yang mendalam dan rinci berkaitan 
dengan suatu peristiwa atau gejala sosial yang dalam hal ini mengenai eksistensi Lembaga Simpan Pinjam Berbasis Masyarakat (LSPBM) dalam pembangunan ekonomi pedesaan. Pendekatan kualitatif juga digunakan untuk mengetahui kondisi tentang permasalahan penelitian yang didasarkan pada pemahaman serta pembentukan pemahaman yang diikat oleh teori terkait dan penafsiran peneliti. Data yang dihasilkan merupakan hasil pengamatan dari kegiatan penelitian terhadap LSPBM terkait. Data tambahan yang berkaitan dengan topik penelitian didapatkan melalui studi dokumen yang relevan dengan fokus penelitian yang digunakan sebagai data tambahan untuk memperkaya penulisan penelitian. Data yang diperoleh secara kualitatif di lapangan akan dikuantifikasi dengan alat analisis yang digunakan yaitu SWOT sehingga diperoleh hasil yang valid dan bisa dipertanggungjawabkan.

\section{Lokasi dan Waktu Penelitian}

Penelitian akan dilaksanakan di lokasi Lembaga Simpan Pinjam Berbasis Masyarakat Usaha Bersama, yang berada di Desa Siboang, Kecamatan Sojol, Kabupaten Donggala, Provinsi Sulawesi Tengah. Lokasi ini diambil karena dari 30 desa yang membentuk LSPBM di Kabupaten Donggala tinggal 1(satu) desa ini yang tetap eksis. Untuk saat ini LSPBM dinilai ideal untuk dijadikan objek penelitian karena telah menjalankan kegiatan selama 12 tahun dengan anggota UMKM yang bergerak di Desa Siboang dan sekitarnya. Penelitian ini dilakukan dalam 4 tahap yang dilakukan pada bulan Agustus 2017 sampai dengan Mei 2018. Tahap pertama yaitu pengumpulan data dan literatur. Tahap kedua yaitu penyusunan proposal penelitian. Tahap ketiga yaitu pengumpulan data untuk pencapaian penelitian. Sedangkan penelitian tahap keempat yaitu pengolahan data sampai penyelesaian draft penelitian.

\section{Sampel Penelitian}

Sampel penelitian ini adalah UMKM dan pengurus LSPBM di Desa Siboang, Kecamatan Sojol, Kabupaten Donggala. Besar ukuran dari UMKM adalah sejumlah 50 UMKM perorangan, dan memilih secara acak UMKM yang tidak tersentuh oleh LSPBM dan 3 orang narasumber dari narasumber ahli sebagai informan dalam penelitian ini yang terdiri dari perwakian Dinas Koperasi Kabupaten Donggala, BMPD Desa Sojol dan Asosiasi LSPBM Kabupaten Donggala. Sedangkan besar ukuran pengurus LSPBM ditentukan secara insedensial di lokasi penelitian.

\section{Teknik Pengumpulan Data}

Data kualitatif yang dihasilkan selama penelitian ini dapat dikelompokkan ke dalam tiga kategori, yaitu: data hasil pengamatan, data hasil pembicaraan dan data tertulis. Data primer dikumpulkan dari UMKM meliputi karakteristik individu, jenis usaha dan persepsinya terhadap LSPBM sedangkan dari pengurus LSPBM terkait 
Nirmala Dewi, Moh. Arafa, Rika Suprapty Peran Lembaga Simpan Pinjam Berbasis Masyarakat (LSPBM) Usaha Bersama Desa Siboang terhadap Pembangunan Ekonomi Pedesaan

dengan profil ke organisasian yaitu pengkategorian LSPBM, historis pembentukan, dimensi organisasi LSPBM, pengembangan skema perkreditan, dan unsur-unsur keberlanjutannya. Pengumpulan data dilakukan melalui kombinasi pendekatan wawancara individual (indepth interview) telaah mendalam dan diskusi kelompok UMKM mengenai peran LSPBM dalam meningkatkan perekonomian Desa Siboang. Data sekunder dikumpulkan dari berbagai sumber kepustakaan dan pelaporan yang terkait dengan pengembangan pelayanan jasa keuangan mikro.

\section{Teknik Analisis Data}

Analisis data kualitatif dilakukan secara berlanjut, berulang, dan terus menerus yang terdiri dari pengumpulan data, analisis data, reduksi data, penyajian data, dan penarikan kesimpulan.Pengumpulan data dan analisis data dilakukan secara bersamaan. Kemudian data tersebut direduksi melalui proses pemilihan dan pengkategorian data-data yang sesuai. Reduksi data bertujuan untuk menajamkan, menggolongkan, mengarahkan, membuang yang tidak perlu, dan mengorganisasikan data sedemikian rupa sehingga kesimpulan akhir strategi pengembangan lembaga keuangan mikro dalam pembangunan ekonomi pedesaan dapat dirancang dengan tepat. Data kuantitatif mengenai penilaian faktor-faktor pengelolaan untuk menentukan arahan strategi pengembangan LSPBM, baik faktor internal maupun eksternal dianalisis dengan analisis SWOT (Strengths, Weaknesses, Opportunities, and Threats) untuk memperoleh arahan kebijakan yang tepat dalam pengembangan LSPBM, khususnya LSPBM di lokasi penelitian. Sebelum melakukan analisis SWOT, perlu melakukan evaluasi terhadap faktor internal dan factor eksternal yang berdampak pada kesuksesan atau kegagalan dalam pengembangan LSPBM. Evaluasi tersebut dalam bentuk matriks Internal Factor Evaluation (IFE) dan External Factor Evaluation (EFE).

\section{Dinamika LSPBM Desa Siboang}

Lembaga Simpan Pinjam Berbasis Masyarakat (LSPBM) Usaha bersama desa Siboang dalam melaksanakan kegiatannya berdasarkan prinsip koperasi yaitu keanggotaan bersifat sukarela dan terbuka dengan prinsip pengelolaan yang demokratis. LSPBM dalam pelaksanaan pembagian sisa hasil usaha (SHU) dilaksanakan setiap tahun yang dibagi kepada seluruh anggota secara adil sebanding dengan jasa usaha masing-masing anggota. Pembagian SHU dilakukan setiap tahun melalui pelaksanaan rapat anggota tahunan (RAT) dan setiap anggota mendapat balas jasa berdasarkan pembagian 60:40 artinya pembagian SHU kepada anggota dari modal usaha adalah 60\% dikembalikan kepada anggota yang dibagi kepada seluruh anggota dan $40 \%$ menjadi bagian untuk operasional dan pemupukkan modal lembaga. LSPBM dalam kegiatannya adalah usaha simpan pinjam dengan mengedepankan 
simpanan sebagai modal usaha. Simpanan terdiri dari simpanan wajib, simpanan pokok, dan sukarela. Ketiga produk simpanan ini merupakan modal lembaga yang terus dipupuk dan dikelola untuk menunjang pertumbuhan modal anggota. Selain itu upaya pengurus adalah meningkatkan modal usaha dalam bentuk simpanan lainnya yaitu simpanan yang berasal dari tabungan anak-anak atau dengan nama tabungan ceria yang tujuannya adalah penggalangan tabungan dan kebiasaan menabung bagi anak-anak desa Siboang.

Lembaga Simpan Pinjam Berbasis Masyarakat (LSPBM) Usaha Bersama Desa Siboang yang dijalankan oleh pengurus berorientasi pada kegiatan simpan pinjam yang diperuntukkan untuk pengembangan usaha anggota. LSPBM Usaha Bersama terbentuk pada tanggal 23 januari 2006 yang awalnya adalah difasilitasi oleh Pemerintah melalui Badan Pemberdayaan Masyarakat Desa (BPMD) melalui program Pemberdayaan Masyarakat untuk Pembangunan Desa (PMPD) atau CERD (Community Empowerman For Rural Development) sejak tahun 2003. Awal pembentukkannya diprakarsai oleh masyarakat desa Siboang yang merupakan pendiri awal LSPBM yang melaksanakan pertemuan di desa Siboang untuk membentuk LSPBM yang kemudian dari hasil kesepakatan pembentukkan tersebut kemudian mensepakati pembentukkan pengurus yang akan membahas tentang Anggaran Dasar (AD) dan Anggaran Rumah Tangga (ART) dan membahas pola pelaksanaan kegiatan LSPBM. Asas LSPBM menitik baratkan pada asas koperasi walaupun tidak berbadan hukum koperasi. LSPBM berdiri atas asas kekeluargaan dan bertujuan bisa mensejahterakan para anggota yang bergabung dalam LSPBM. Jenis usaha - usaha yang sudah mendapatkan pinjaman ataupun pembiayaan dari LSPBM bergerak dalam kelompok usaha produksi, pengolahan, dagang kelompok prasejahtera.

\section{Kebutuhan Dasar LSPBM Usaha Bersama Desa Siboang dalam Menyalurkan Dana}

Simpanan LSPBM terdiri dari simpanan pokok yang dibayarkan sekali selama menjadi anggota sebesar Rp100.000,00 simpanan wajib yang dibayarkan setiap bulan sebesar Rp15.000,00/bulan dan merupakan kewajiban anggota dan besarannya dituangkan dalam AD-ART. Setiap anggota mempunyai kewajiban untuk membayar simpanan wajib yang sudah menjadi ketentuan di LSPBM Usaha Bersama dan selain simpanan pokok dan wajib jenis simpanan lain yang dilakukan oleh LSPBM Usaha Bersama adalah simpanan sukarela, dan simpanan ini tidak ada ketentuan jumlahnya dan simpanan sukarela boleh dilakukan juga oleh non anggota LSPBM yang ingin melakukan investasi di LSPBM. Pertumbuhan simpanan sampai dengan Desember 2017 adalah berjumlah Rp638.966.350,00 ini memberikan gambaran bahwa sejak 10 tahun terakhir ini rata-rata anggota/UMKM telah menyimpan dananya sebesar 
Nirmala Dewi, Moh. Arafa, Rika Suprapty Peran Lembaga Simpan Pinjam Berbasis Masyarakat (LSPBM) Usaha Bersama Desa Siboang terhadap Pembangunan Ekonomi Pedesaan

Rp63.896.635,00/tahun ini memberikan gambaran kemampuan masyarakat menyimpan uang di LSPBM yang cukup besar bisa dihimpun oleh LSPBM dari anggotanya dan ini menggambarkan bahwa kemampuan ekonomi masyarakat desa Siboang untuk menempatkan dananya di LSPBM memberikan gambaran pertumbuhan ekonomi desa sudah cukup baik.

LSPBM dalam rangka meningkatkan modal yang tersedia yang berasal dari simpanan anggota adalah dengan menerapkan kebijakan tentang pinjaman dan besaran pinjaman yang cairkan kepada anggota ditentukan adalah berdasarkan agunan simpanan anggota. Setiap anggota dengan jumlah simpanan minimal adalah berjumlah Rp500.000 rata-rata mendapat pinjaman Rp5.000.000 sampai Rp60.000.000,00. Pinjaman yang diberikan kepada anggota dalam rangka menopang perkembangan usaha anggota dan pinjaman dikenakan bunga sebesar 3\% serta biaya administrasi $1,5 \%$. Total pinjaman yang sudah beredar dianggota sampai dengan 31 desember 2016 adalah berjumlah Rp2.394.550.000,00 secara rata-rata pertahun LSPBM Usaha Bersama menyalurkan kreditnya untuk anggota adalah Rp239.455.000,00. Dengan besaran pinjaman tersebut memberikan gambaran bahwa potensi berkembangnya ekonomi desa ditopang oleh pinjaman yang beredar pada anggota sudah cukup baik.

Modal yang bergulir dalam LSPBM Usaha bersama berasal dari simpanan anggota dan bantuan pemerintah sebesar Rp50.000.000,00 yang diberikan kepada LSPBM Usaha Bersama. Namun modal yang lebih besar berasal dari simpanan anggota yang dimanfaatkan untuk mengembangkan usaha anggota dari jenis UMKM yang bergabung dalam LSPBM Usaha Bersama. Jumlah total modal anggota yang berasal dari simpanan anggota dan hibah operasional sampai dengan periode Desember 2016 adalah berjumlah Rp608.854.325,00 dan modal ini terus digulirkan kepada anggota dan setiap tahun terjadi kenaikan diakibatkan adanya pemupukkan modal yang berasal dari SHU yang dibagikan setiap tahun dengan porsi 60\%:40\%. Adapun Porsi SHU dibagi berdasarkan ketentuan dalam AD-ART yaitu, 30\% digunakan sebagai cadangan dan pemupukkan modal, $15 \%$ jasa pengurus dan pengawas, $10 \%$ Dana pendidikan, promosi dan pembinaan, 5\% dana sumbangan sosial dan pembangunan desa, 40\% dibagikan kepada anggota LSPBM dalam bentuk Deviden anggota.

Dalam pelaksanaan RAT setiap tahun LSPBM telah membagi porsi SHU berdasarkan ketentuan tersebut dan ini merupakan bentuk transparansi dan akuntabel pengurus terhadap alokasi SHU kepada anggota LSPBM Usaha Bersama. Alokasi SHU yang dibagi berdasarkan persentasi adalah upaya pemupukan modal LSPBM Usaha Bersama sehingga setiap tahun terjadi penambahan jumlah modal dari usaha yang dilakukan oleh pengurus dan anggota LSPBM Usaha bersama. Semakin besar 
modal yang dikelola, semakin banyak jumlah pinjaman yang dapat disalurkan kepada anggota sehingga setiap tahun modal akan semakin berkembang dan akan mendorong tumbuhnya usaha-usaha mikro anggota yang bisa dikembangkan dan akan berdampak pada pertumbuhan ekonomi desa. Modal LSPBM Usaha bersama dialokasikan dari simpanan wajib dan simpanan pokok serta pemupukkan modal dari dana penyertaan serta hibah serta cadangan dan dana resiko pinjaman. Modal yang diberikan kepada anggota adalah berupa uang yang diajukan sebagai pinjaman.

\section{Peranan LSPBM dalam Perekonomian Pedesaan dalam Bidang Ekonomi}

Keberadaan LSPBM Usaha Bersama di Desa Siboang terus mengalami perkembangan baik perkembangan anggota maupun perkembangan modal. Tujuan berdirinya LSPBM Usaha Bersama adalah untuk memajukan anggota khususnya dan masyarakat pada umumnya dengan menggerakkan usaha anggota dan pelayanan terhadap anggota terutama dari sisi permodalan anggota berjalan lancar walaupun masih terdapat kredit macet. Belajar dari pengalaman untuk pemberian pinjaman serta menghindari kredit macet maka pengurus LSPBM dalam pelayanan pinjaman selain agunan simpanan apabila kredit dalam jumlah besar di atas Rp5.000.000,00 disertakan agunan berupa sertifikat tanah atau BPKB kendaraan bermotor, dan hal ini dinilai cukup berhasil selama dua tahun terakhir. LSPBM lebih memaksimalkan perannya sebagai lembaga simpan pinjam dengan mengedapankan asas kekeluargaan dan kehadiran LSPBM Usaha Bersama bertempat di dusun II desa Siboang cukup berperan dalam menopang sektor perekonomian desa yang antara lain (1) setiap tahun keanggotaan bertambah dan sampai dengan tahun 2017 jumlah anggota mencapai 316 orang dan rata-rata anggota sudah dilayani oleh LSPBM dari sisi permodalan antara 4 sampai 5 kali bergulir. Jumlah pinjaman terbesar anggota mencapai Rp60.000.000,00 perorang dengan batas waktu pengembalian 6 bulan. Untuk pinjaman sampai dengan Rp5.000.000,00 batas waktu pengembalian 4 bulan. Dalam 1 tahun setiap anggota bisa dilayani 2 sampai 3 kali. Kelompok yang paling banyak terlayani adalah pada sektor usaha dagang jumlah pinjaman dicairkan sejak awal pembentukkan sampai dengan Desember 2016 mencapai Rp10.177.250.000,00 dan yang dicairkan pada bulan Desember 2016 sejumlah Rp97.800.000,00 kepada 10 orang anggota.(data terlampir), dan (2) LSPBM dengan pembiayaan mikro hadir dalam rangka memberikan kemudahan akses modal berupa uang kepada anggota LSPBM Usaha Bersama sesuai AD-ART, dan dalam jangka pendek diharapkan mampu memenuhi kebutuhan permodalan anggota sehingga usahanya dapat berjalan. Dengan demikian dapat menumbuhkan ekonomi pesedaan. 
Nirmala Dewi, Moh. Arafa, Rika Suprapty Peran Lembaga Simpan Pinjam Berbasis Masyarakat (LSPBM) Usaha Bersama Desa Siboang terhadap Pembangunan Ekonomi Pedesaan

\section{Peranan LSPBM dalam Perekonomian Pedesaan dalam Bidang Sosial}

LSPBM Usaha Bersama dalam bidang sosial dirasakan oleh anggota maupun masyarakat desa Siboang cukup memberikan manfaat karena dengan berlandaskan pada asas kekeluargaan telah ikut memberikan alokasi dari SHU berupa dana sosial kepada anggota dan masyarakat dengan persentasi dari SHU sebesar 5\%. Dari alokasi dana sosial ini antara lain diberikan berupa santunan kepada anak yatim dan janda yang membutuhkan biaya hidup. Alokasi dana sosial dan pembangunan diserahkan ke desa untuk digunakan untuk pembangunan sarana dan prasarana desa yang menjadi kebutuhan masyarakat. Santunan ini dimaksud untuk menciptakan rasa kebersamaan dianatara anggota dan masyarakat di desa Siboang. Hal ini juga merupakan upaya pemberdayaan masyarakat sehingga ada keinginan untuk terus mengembangkan usaha LSPBM karena LSPBM Usaha bersama terus maju dan berkembang.

\section{Kekuatan (Strengths)}

\section{Mengurangi Keparahan (Saverity) Kemiskinan}

LKM atau LSPBM berperan sebagai lembaga keuangan mikro yang salah satu tujuannya adalah pengembangan usaha mikro dan kecil untuk meningkatkan usaha anggota sebagai upaya pengentasan kemiskinan. Kehadiran LSPBM akan membantu akses permodalan bagi penduduk miskin sehingga diharapkan akan mengurangi tingkat kemiskinan di masyarakat. Kemudahan dalam pengembangan usaha adalah salah satu upaya penanggulangan kemiskinan dan mengurangi tingkat keparahan (saferity) kemiskinan.

\section{Peningkatan Simpanan}

Keberadaan LSPBM sebagai upaya untuk menghimpun dana-dana dari masyarakat dalam bentuk simpanan karena peran LSPBM adalah sebagai lembaga yang melakukan pengelolaan simpan pinjam. Menjadi anggota LSPBM bertujuan membiasakan anggota dan masyarakat untuk menabung/ menyimpan dari penghasilannya dan menabung dari kekurangan anggota. Setiap anggota yang menjadi anggota LSPBM mempunyai kewajiban untuk membayar simpanan pokok dan simpanan wajib sehingga LSPBM terus melakukan peningkatan simpanan anggota.

\section{Peningkatan Kapasitas Investasi}

LSPBM dalam rangka melakukan penggalangan simpanan anggota merupakan salah satu upaya untuk melakukan peningkatan modal semakin tinggi modal maka akan semakin tinggi pula kapasitas Investasi LSPBM. Meningkatnya Investasi LSPBM berarti akan berdampak pada meningkatnya kapasitas investasi anggota. 


\section{Memungkinkan Pola Konsumsi yang Lebih Pasti}

Dengan adanya kebiasaan menabung maka setiap anggota LSPBM punya peluang untuk merubah pola konsumsi karena ada kewajiban untuk membayar simpanan sehingga semakin meningkat pola hidupnya akan berpengaruh pada pola konsumsi yang lebih pasti.

\section{Mengurangi Kebutuhan Meminjam dari Rentenir dengan Bunga Tinggi}

Lembaga keuangan mikro atau LSPBM merupakan salah satu bentuk upaya untuk membantu masyarakat pada umumnya dan anggota LSPBM khususnya agar terlayani dalam pelayanan kredit dengan bunga murah dan kemudahan-kemudahan dalam bertransaksi. Hal ini dimaksudkan agar anggota dalam memenuhi kebutuhan modal usaha tidak meminjam pada pihak rentenir yang dalam memberikan pinjaman kepada masyarakat menggunakan bunga tinggi, sehingga anggota LSPBM dan masyarakat dapat mengatasi kebutuhan investasi hanya melalui LSPBM dan mengurangi kebutuhan meminjam pada rentenir.

\section{Mengurangi Tekanan Untuk Menjual Aset}

Kehadiran LSPBM di harapkan dapat menjembatani kesulitan masyarakat dan anggota LSPBM dalam memenuhi kebutuhan hidup, terutama anggota ataupun masyarakat yang terdesak untuk memenuhi kebutuhan hidup sehingga jalan yang paling mudah dilakukan adalah menjual aset. Hal ini terjadi disebabkan karena tidak tersedianya dana yang dibutuhkan untuk pengelolaan usaha, dan karena tekanan ekonomi maka jalan yang dilakukan oleh masyarakat adalah menjual aset. LSPBM menjadi salah satu alternatif untuk mengurangi tekanan menjual aset.

\section{Peningkatan Pendapatan}

Dengan masuk menjadi anggota LSPBM ada kemudahan akses modal usaha dan perluasan usaha. Meningkatnya usaha maka akan berdampak pada peningkatan pendapatan, dan LSPBM dapat memberikan kemudahan kepada anggota untuk meningkatkan pinjaman investasi untuk perluasan usaha mikro. LSPBM dapat memberikan pinjaman 5 jt-60 jt untuk usaha mikro dengan bunga yang rendah 3\%$4,5 \%$ untuk jenis usaha yang diajukan berdasarkan kebutuhan.

\section{Kepercayaan (Trust)}

LSPBM Usaha Bersama terbangun atas asas kekeluargaan dan kebersamaan yang telah mengakar antara pengurus dengan anggota, hal ini merupakan nilai tambah bagi LSPBM yang telah dipercaya oleh masyarakat dalam pengelolaan dana simpan pinjam. Kepercayaan masyarakat adalah hal terpenting bagi kelangsungan proses 
Nirmala Dewi, Moh. Arafa, Rika Suprapty Peran Lembaga Simpan Pinjam Berbasis Masyarakat (LSPBM) Usaha Bersama Desa Siboang terhadap Pembangunan Ekonomi Pedesaan

pengelolaan LSPBM sehingga bukan hanya sekedar nilai ekonomi saja yang terpenuhi tetapi jalinan sosial juga terbangun.

\section{Pemberdayaan}

Dalam kegiatan LSPBM yang bergerak pada usaha simpan pinjam lebih mengedepankan proses pemberdayaan karena setiap anggota dan masyarakat mendapatkan kemudahan akses untuk mengembangkan potensi usaha yang ada. Pemberdayaan menjadi salah satu tujuan dari LSPBM dalam menggerakkan kepedulian masyarakat untuk saling berbagi dan bekerjasama dalam kelompok. Kepedulian akan kesulitan dapat dijembatani oleh LSPBM dengan memberikan kemudahan dalam melakukan akses modal untuk kesejahteraan masyarakat lokal.

\section{Kelemahan (Weakness)}

\section{Manajemen Lemah}

Pengaturan dan berbagi peran dalam menjalankan fungsinya sangat penting dalam sebuah organisasi. Lemahnya manajemen LSPBM Usaha Bersama membuat pengelolaan modal belum efektif, hal ini disebabkan dalam struktur organisasi yang ada hanya terdapat 3 orang pengurus dan 1 orang staf administrasi dan umum dan proses pencatatan masih dengan cara manual.

\section{Pengembalian Kredit Sulit/ Macet}

LSPBM Usaha Bersama dalam memberikan kredit kepada anggota tidak berdasarkan pertimbangan proposal usaha sehingga terjadi kredit macet di anggota. Anggota yang tersebar selain di desa juga terdapat di desa sekitar desa Siboang menjadi jangkauan yang sulit untuk melakukan tagihan dan kesadaran mengembalikan kredit menjadi kendala dari anggota LSPBM untuk membayar pinjaman tepat waktu.

\section{Tidak Memiliki Badan Hukum/ Legalitas}

Ketidak jelasan Undang-undang yang mengatur tentang Lembaga Keuangan Mikro (LKM) sehingga sampai saat ini LSPBM Usaha Bersama belum memiliki badan hukum sebagai legalitas formal. Yang menjadi acuan hanya dengan kekuatan AD-ART LSPBM Usaha Bersama yang ditinjau kembali setiap 5 tahun sekali sebagai acuan kesepakatan dengan anggota LSPBM Usaha Bersama untuk berhubungan dengan pihak ketiga sulit karena tidak adanya legalitas formal LSPBM. Para penabung/ deposan/ anggota sama sekali tidak memperoleh perlindungan hukum.

\section{Keterbatasan dalam Akses Permodalan}

Modal LSPBM yang selama ini dilakukan adalah berasal dari simpanan anggota dan modal bantuan hibah yang baru dilakukan 1 kali sejak LSPBM Usaha 
Bersama beroperasi. Namun telah dilakukan pula penambahan dari SHU yang alokasinya setiap tahun didapatkan dari sistem bagi hasil, semuanya terkait dengan penambahan permodalan usaha selain simpanan hutang yang dilakukan masyarakat dalam bentuk simpanan sukarela, namun pertambahannya kecil dan lambat sementara kebutuhan anggota cukup banyak untuk bisa mengases modal. Karena berkaitan legalitas formal yang belum ada, LSPBM mengalami keterbatas dalam mengakses modal diperbankan formal.

\section{Peluang (Opportunities)}

\section{Adanya Kewajiban Negara untuk Mensejahterakan Kehidupan Masyarakat Indonesia}

Dalam rangka menjalankan amanat UUD 1945 maka kehadiran LSPBM Usaha Bersama adalah merupakan salah satu bentuk perhatian terhadap upaya- upaya dalam meningkatkan kesejahteraan masyarakat. LSPBM dapat memberikan kemudahan dalam mengakses modal serta mendapatkan pinjaman dengan cepat tanpa harus melengkapi persyaratan yang panjang.

\section{Perubahan Paradigma Pemerintah dalam Mengalokasikan Sumber-sumber Daya Ekonomi}

Prinsip budget for poor policy menjadi salah satu bentuk kebijakan yang berpihak pada kepentingan masyarakt miskin, perubahan paradigma pemerintah dalam peningkatan sumber daya masyarakat adalah untuk mengalokasikan sumber daya ekonomi agar dapat mengatasi tingkat kemiskinan.

\section{Otonomi Daerah Membuka Ruang Partisipasi}

Otonomi daerah merupakan salah satu upaya pemerintah daerah dalam mengatur regulasi daerah terkait dengan kebijakan yang berpihak pada kepentingan masyarakat. Otonomi daerah juga membuka ruang partisipasi bagi pihak swasta dan civil society ikut berperan dalam penanggulan kemiskinan karena adanya tuntutan terhadap pihak swasta untuk mengalokasikan sebagian profit yang diperoleh bagi kesejahteraan masyarakat lokal.

\section{UMKM Berpotensi dalam Melakukan Kerjasama}

Semakin berkembangnya usaha simpan pinjam LSPBM Usaha Bersama Desa Siboang hal ini dapat menjadikan tumbuhnya UMKM-UMKM yang dapat mengakses modal dan memperluas usaha dan mejalin kerjasama dengan UMKM lainnya yang berpotensi untuk pengembangan usaha.Untuk itu dibutuhkan upaya penyaluran kredit dengan sifatnya lebih fleksibel. 
Nirmala Dewi, Moh. Arafa, Rika Suprapty Peran Lembaga Simpan Pinjam Berbasis Masyarakat (LSPBM) Usaha Bersama Desa Siboang terhadap Pembangunan Ekonomi Pedesaan

\section{Ancaman (Threats)}

\section{Persyaratan Teknis Kurang Dipenuhi}

LSPBM Usaha Bersama Desa Siboang dalam penyaluran kredit tidak menggunakan pertimbangan proposal usaha, karena proposal usaha tidak menjadi persyaratan untuk pengajuan kredit dan hal ini yang menjadikan pemberian kredit tidak relevan dengan kebutuhan usaha sehingga dapat menimbulkan kredit macet.

\section{Rendahnya Profesionalisme}

Sistem kerja yang dilakukan di LSPBM Usaha bersama masih bersifat manual sehingga fungsi serta peran pengurus belum berjalan optimal dan kurang efektif dalam bekerja. Pengurus merangkap pengelola hal ini menjadi tidak bisa menentukan pola kebijakan yang efektif. Masih lemahnya manajemen pengelolaan terlihat dalam penetuan kebijakan pemberian pinjaman kepada angggota yang tidak mempunyai acuan skim.

\section{Bantuan Teknis Kurang Efektif}

Lemahnya manajemen di LSPBM disebabkan karena kurangnya bantuan teknis yang didapatkan oleh LSPBM Usaha Bersama dan hal ini sangat menentukan kualitas kerja LSPBM yang belum efektif. Hal ini akan berdampak pada ketidakmampuan dalam pengelolaan modal usaha LSPBM karena perputaran modal tidak efektif.

Tabel 1. Faktor Internal LSPBM Usaha Bersama di Desa Siboang Tahun 2017

\begin{tabular}{lccc}
\hline \multicolumn{1}{c}{ Faktor Internal } & Bobot & Rating & Skor \\
\hline \hline Kekuatan dan Kelemahan & & & \\
\hline S1 Mengurangi Keparahan (Savety) kemiskinan & 0,05 & 1 & 0,05 \\
\hline S2 Peningkatan Simpanan & 0,110 & 2 & 0,22 \\
\hline S3 Memungkinkan Pola Konsumtif Lebih Pasti & 0,05 & 1 & 0,05 \\
\hline S4 Peningkatan Kapasitas Investasi & 0,120 & 2 & 0,24 \\
\hline S5 Mengurangi Kebutuhan Meminjam dari Rentenir dengan bunga tinggi & 0,10 & 2 & 0,2 \\
\hline S6 Peningkatan Pendapatan & 0,125 & 3 & 0,375 \\
\hline S7 Kepercayaan & 0,155 & 4 & 0,62 \\
\hline S8 Pemberdayaan & 0,05 & 1 & 0,05 \\
\hline W1 Manajemen Lemah & 0,05 & 1 & 0,05 \\
\hline W2 Pengembalian Kredit Sulit/ Macet & 0,10 & 2 & 0,2 \\
\hline W3 Tidak Memiliki Badan Hukum/Legalitas & 0,05 & 1 & 0,05 \\
\hline W4 Keterbatasan dalam Akses Permodalan & 0,05 & 1 & 0,05 \\
\hline Total Faktor Internal & 1,000 & & 2,105 \\
\hline Sumber: data diolah & & &
\end{tabular}

Sumber: data diolah

Berdasarkan perhitungan yang dilakukan dengan menggunakan analisa SWOT didapat bahwa faktor internal yang paling besar adalah S6, yaitu kepercayaan terhadap LSPBM Usaha Bersama yang didasari oleh asas kebersamaan dan kekeluargaan. Nilai 4,0 diperoleh dari pengalian antara bobot dan rating yang 
diberikan oleh responden, yaitu Sekdes, Tokoh Masyarakat, Ketua LSPBM, Seketaris, Bendahara dan Dewan Pengawas LSPBM Usaha Bersama Desa Siboang. Penilaian faktor-faktor internal selengkapnya dapat dilihat di tabel 1.

Berdasarkan perhitungan yang dilakukan dengan menggunakan analisa SWOT didapat bahwa faktor ekternal yang paling besar adalah O4, yaitu UMKM berpotensi melakukan kerjasama terhadap LSPBM Usaha Bersama untuk menumbuhkan potensi ekonomi dan modal untuk pengembangan usaha. Nilai 3,4 diperoleh dari pengalian antara bobot dan rating yang diberikan oleh responden, yaitu Sekdes, Tokoh Masyarakat, Ketua LSPBM, Seketaris, Bendahara dan Dewan Pengawas LSPBM Usaha Bersama Desa Siboang. Penilaian faktor-faktor eksternal selengkapnya dapat dilihat di tabel 2.

Tabel 2. Faktor Eksternal LSPBM Usaha Bersama di Desa Siboang Tahun 2017

\begin{tabular}{lcccc}
\hline & Faktor Ekternal & Bobot & Rating & Skor \\
\hline Peluang dan Ancaman & & & & \\
\hline $\begin{array}{l}\text { O1 Adanya kewajiban negara } \\
\text { masyarakat Indonesia }\end{array}$ & untuk mensejahterakan kehidupan & 0,10 & 2 & 0,2 \\
\hline $\begin{array}{l}\text { O2 Perubahan paradigma pemerintah dalam mengelolah sumber-sumber } \\
\text { daya ekonomi }\end{array}$ & 0,15 & 3 & 0,45 \\
\hline O3 Otonomi daerah membuka ruang partisipasi & 0,15 & 3 & 0,45 \\
\hline O4 UMKM berpotensi dalam melakukan kerjasama & 0,30 & 4 & 1,2 \\
\hline T1 Persyaratan teknis kurang dipenuhi & 0,126 & 2 & 0,252 \\
\hline T2 Rendahnya Profesionalisme & 0,05 & 1 & 0.05 \\
\hline T3 Bantuan teknis kurang efektif & 0,124 & 2 & 0,248 \\
\hline Total Faktor Ekternal & 1,000 & & 2,85 \\
\hline Sum
\end{tabular}

Sumber: Data diolah

Perhitungan Kekuatan, Kelemahan, Peluang dan Ancaman LSPBM Usaha Bersama Desa Siboang mengahasilkan nilai 1,895 untuk kekuatan, 0,35 untuk kelemahan, 2,30 untuk peluang, dan 0,550 untuk ancaman. Uraian analisis SWOT akan menghasilkan strategi dasar dengan menggunakan kekuatan sebagai modal dasar dalam mengembangkan potensi LSPBM Usaha Bersama dan memanfaatkan kesempatan sebaik-baiknya serta mencoba mengantisipasi dan mencegah ancaman yang datang dari luar dan strategi yang dihasilkan dapat mengurangi kelemahan yang ada pada sistem di LSPBM Usaha Bersama.

\section{Analisis SWOT pada LSPBM}

Analisis SWOT dilakukan untuk menghasilkan berbagai strategi terkait pengembangan LSPBM Usaha Bersama. Analisis dilakukan terhadap faktor-faktor internal dan ekternal, sehingga dari hasil analisis yang merupakan kombinasi antara: SO (Strength - Opportunities), WO (Weakness - Opportunities), ST (Strength - 
Nirmala Dewi, Moh. Arafa, Rika Suprapty Peran Lembaga Simpan Pinjam Berbasis Masyarakat (LSPBM) Usaha Bersama Desa Siboang terhadap Pembangunan Ekonomi Pedesaan

Threats) dan WT (Weakness - Threats). Kombinasi S-W-O-T dapat dilihat selengkapnya di lampiran.

Alternatif strategi pengembangan LSPBM Usaha Bersama dapat diperoleh setelah dilakukan analisis terhadap faktor-faktor internal dan ekternal. Hasil analisis matriks SWOT yang merupakan kombinasi SO (Kekuatan - Peluang), WO (Kelemahan - Peluang), ST (Kekuatan - Ancaman), dan WT (Kelemahan Ancaman). Hasil analisis menghasilkan beberapa alternatif antara lain, (1) (SO1) mendorong LSPBM untuk terus meningkatkan modal usaha dengan pola simpanan agar membiasakan menabung pada anggota LSPBM dan mendorong pendampingan pada LSPBM, (2) SO2 mengembangkan dan menguatkan kerjasama dengan dunia usaha dalam pengelolaan potensi ekonomi dan membangun jaringan dengan dunia usaha dan peningkatan sumber daya manusia dalam pengelolaan sumber - sumber ekonomi, (3) SO3 peningkatan dan Pengembangan kemampuan SDM dan memperluas pasar serta meningkatkan produktifitas UMKM, (4) SO4 mengembangkan dan menguatkan kerjasama dengan UMKM dalam bentuk kerjasama bisnis, sharing dan kompetisi dan hal positif lainnya, (5) WO1 peningkatan Kapasitas SDM dalam pengelolaan dengan mengikuti atau melaksanakan pendidikan, ketrampilan bagi pengurus, pengawas LSPBM, (6) WO2 melakukan koordinasi dalam pengelolaan sumber - sumber potensi ekonomi agar lebih dikembangkan serta mem bangun jaringan kerjasama dengan UMKM dalam skala desa dan antar desa, (7) WO3 berkoordinasi dengan Dinas terkait menyangkut pembinaan terhadap LSPBM dan Badan hukum sebagai legalitas LSPBM, (8) WO4 mencari jaringan kerja dan aktif dalam memperluas dunia usaha serta bekerjasama dengan sistem channeling dengan lembaga keuangan formal dan non formal untuk mengakses modal, (9) ST1 memberikan pelatihan pada UMKM dalam pembuatan proposal serta persyaratan teknis dalam peningkatan usaha UMKM, (10) ST2 meningkatkan pola rekrutmen dalam pengurus untuk meningkatkan kapasitas dan bekerjsama dengan Dinas terkait dalam pembinaan, (11) ST3 meningkatkan jaringan dan koordinasi dengan pemerintah dan swasta serta memperluas kerjasama UMKM, (12) WT1 meningkatkan mutu pengelola melalui pelatihan dan bimtek dan melakukan koordinasi dengan dinas terkait, (13) WT2 memperkuat persyaratan teknis dalam prosedure peminjaman kredit kepada anggota dan UMKM dan menigkatkan kapasitas pengurus dalam pengelolaan serta perlunya penambahan staff kantor, (14) WT3 memperkuat struktur organisasi dan Identifikasi dalam mengelola usaha di desa Siboang dan melakukan peninjauan terhadap AD-ART.

Berdasarkan tabel 3, didapat 4 alternatif strategi yang menjadi prioritas utama dalam upaya pengembangan LSPBM Usaha Bersama di Desa Siboang meliputi: (1) mengembangkan dan menguatkan LSPBM Usaha Bersama dengan UMKM- 
UMKM dalam bentuk kerjasama bisnis, sharing dan kompetisi dan hal positif lainnya dalam rangka meningkatkan layanan dan jaringan hingga jangkauan pelayanan untuk terus memperkuat LSPBM Usaha Bersama di Desa Siboang, (2) mendorong LSPBM untuk terus meningkatkan modal usaha dengan pola simpanan agar membiasakan menabung pada anggota LSPBM dan mendorong pendampingan pada LSPBM Usaha Bersama di desa Siboang, (3) meningkatan dan Pengembangan kemampuan SDM melalui pelatihan-pelatihan kerjasama dengan Pemerintah untuk mendorong potensi SDM yang ada di desa Siboang agar pengelolaan LSPBM lebih optimal dan profesional dan memperluas pasar serta meningkatkan produktifitas UMKM, (4) mengembangkan dan menguatkan kerjasama dengan dunia usaha dalam pengelolaan potensi ekonomi dan membangun jaringan dengan dunia usaha dan peningkatan sumber daya manusia dalam pengelolaan sumber-sumber ekonomi yang ada di desa dan sekitar desa di wilayah kecamatan Sojol agar ekonomi desa tumbuh dan berkembang.

Tabel 3. Peratingan Alternatif Strategi Pengembangan LSPBM Usaha Bersama Desa Siboang

\begin{tabular}{cccc}
\hline Alternatif Strategi & Keterkautan Unsur SWOT & Nilai & Rating \\
\hline SO1 & $(\mathrm{S} 2, \mathrm{~S} 3, \mathrm{~S} 4, \mathrm{~S} 5, \mathrm{~S} 6, \mathrm{~S} 7, \mathrm{~S} 8, \mathrm{O} 2, \mathrm{O} 3, \mathrm{O} 4)$ & 3,605 & 2 \\
\hline SO2 & $(\mathrm{S} 3, \mathrm{~S} 6, \mathrm{~S} 7, \mathrm{~S} 8, \mathrm{O} 1, \mathrm{O} 2, \mathrm{O} 3, \mathrm{O} 4)$ & 3,395 & 4 \\
\hline SO3 & $(\mathrm{S} 2, \mathrm{~S} 3, \mathrm{~S} 5, \mathrm{S6} 6, \mathrm{~S} 7, \mathrm{~S} 8, \mathrm{~S} 9, \mathrm{O} 2, \mathrm{O} 3, \mathrm{O} 4)$ & 3,565 & 3 \\
\hline SO4 & $(\mathrm{S} 1, \mathrm{~S} 2, \mathrm{~S} 3, \mathrm{~S} 5, \mathrm{~S} 6, \mathrm{~S} 7, \mathrm{~S} 8,, \mathrm{O} 1, \mathrm{O} 2, \mathrm{O} 3, \mathrm{O} 4)$ & 3,865 & 1 \\
\hline WO1 & $(\mathrm{W} 1, \mathrm{~W} 2, \mathrm{~W} 3, \mathrm{O} 1, \mathrm{O} 2, \mathrm{O} 3)$ & 1,4 & 9 \\
\hline WO2 & $(\mathrm{W} 2, \mathrm{~W} 3, \mathrm{O} 2, \mathrm{O} 3, \mathrm{O} 4)$ & 2,35 & 7 \\
\hline WO3 & $(\mathrm{W} 1, \mathrm{~W} 2, \mathrm{~W} 3, \mathrm{~W} 4 . \mathrm{O} 2, \mathrm{O} 3)$ & 1,25 & 11 \\
\hline WO4 & $(\mathrm{W} 2, \mathrm{~W} 3, \mathrm{~W} 4, \mathrm{O} 1, \mathrm{O} 2, \mathrm{O} 3, \mathrm{O} 4)$ & 2,6 & 6 \\
\hline ST1 & $(\mathrm{S} 2, \mathrm{~S} 3, \mathrm{~S} 4, \mathrm{~S} 5, \mathrm{~S} 6, \mathrm{~S} 7, \mathrm{~S} 8, \mathrm{~T} 2, \mathrm{~T} 3)$ & 2,053 & 8 \\
\hline ST2 & $(\mathrm{S} 3, \mathrm{~S} 7, \mathrm{~S} 8, \mathrm{~T} 1, \mathrm{~T} 2, \mathrm{~T} 3)$ & 1,27 & 10 \\
\hline ST3 & $(\mathrm{S} 2, \mathrm{~S} 3, \mathrm{~S} 4, \mathrm{~S} 6, \mathrm{~S} 7, \mathrm{~S} 8, \mathrm{~T} 1, \mathrm{~T} 2, \mathrm{~T} 3)$ & 2,605 & 5 \\
\hline WT1 & $(\mathrm{W} 1, \mathrm{~W} 2, \mathrm{~W} 4, \mathrm{~T} 1, \mathrm{~T} 2, \mathrm{~T} 3)$ & 0,85 & 14 \\
\hline WT2 & $(\mathrm{W} 1, \mathrm{~W} 2, \mathrm{~W} 3, \mathrm{~W} 4, \mathrm{~T} 1, \mathrm{~T} 2, \mathrm{~T} 3)$ & 0,9 & 12 \\
\hline WT3 & $(\mathrm{W} 1, \mathrm{~W} 2, \mathrm{~W} 3, \mathrm{~W} 4, \mathrm{~T} 1, \mathrm{~T} 2, \mathrm{~T} 3)$ & 0,9 & 13 \\
\hline S2 & &
\end{tabular}

Sumber: data diolah

\section{KESIMPULAN}

Kemampuan masyarakat menyimpan uang di LSPBM yang cukup besar bisa dihimpun oleh LSPBM dari anggotanya dan ini menggambarkan bahwa kemampuan ekonomi masyarakat desa Siboang untuk menempatkan dananya di LSPBM memberikan gambaran pertumbuhan ekonomi desa sudah cukup baik. Selain itu, LSPBM dalam rangka meningkatkan modal yang tersedia yang berasal dari simpanan anggota adalah dengan menerapkan kebijakan tentang pinjaman dan besaran 
Nirmala Dewi, Moh. Arafa, Rika Suprapty Peran Lembaga Simpan Pinjam Berbasis Masyarakat (LSPBM) Usaha Bersama Desa Siboang terhadap Pembangunan Ekonomi Pedesaan

pinjaman yang dicairkan kepada anggota ditentukan adalah berdasarkan agunan simpanan anggota. Besaran pinjaman masyarakat memberikan gambaran bahwa potensi berkembangnya ekonomi desa ditopang oleh pinjaman yang beredar pada anggota sudah cukup baik. LSPBM Usaha Bersama desa Siboang berperan cukup besar dalam mendorong ekonomi lokal di mana sejak berdiri tahun 2006 hingga tahun 2016 jumlah anggota LSPBM terus terjadi peningkatan.

Model pengembangan LSPBM Usaha bersama desa Siboang berdasarkan pemilihan strategi alternatif utama (a) mengembangkan dan menguatkan LSPBM Usaha Bersama dengan UMKM-UMKM dalam bentuk kerjasama bisnis, sharing dalam rangka meningkatkan layanan dan jangkauan pelayanan, (b) meningkatkan modal usaha dengan pola simpanan untuk membiasakan menabung pada anggota LSPBM Usaha Bersama Desa Siboang, (c) mendorong pendampingan LSPBM Usaha Bersama desa Siboang melalui instansi terkait dan PEMDA Donggala untuk pengawasan dan pengembangan kelembagaan, peningkatan SDM pengelola LSPBM Usaha Bersama desa Siboang agar pengelolaan lebih optimal dan profesional, dan (d) mengembangkan dan menguatkan kerjasama dengan dunia usaha dalam pengelolaan potensi ekonomi dan membangun jaringan dengan dunia usaha dan peningkatan sumber daya manusia dalam pengelolaan sumber-sumber ekonomi.

Perlu ada peningkatan kualitas dari pengurus LSPBM Usaha Bersama desa Siboang agar mampu mengelolah LSPBM Usaha Bersama lebih optimal dan profesional untuk menghindari penyimpangan dalam pengelolaan dan dapat meningkatkan akses modal serta pembinaan pada UMKM-UMKM anggota LSPBM Usaha Bersama desa Siboang. Memastikan payung hukum bagi LSPBM Usaha Bersama desa Siboang untuk lebih meningkatkan kepercayaan pihak ke-3 dalam rangka peningkatan kerjasama dengan lembaga keuangan formal dan dinas terkait untuk memperoleh dana guna penigkatan investasi dan modal usaha dan diperlukan pendampingan untuk mendukung keberlanjutan LSPBM Usaha Bersama desa Siboang agar LSPBM dapat terus eksis memberikan pelayanan dan meningkatkan perekonomian desa.

Keterbatasan dalam penelitian ini adalah penelitian masih dilakukan di satu wilayah yaitu LSPBM usaha bersama di Desa Sojol, Kecamatan Damsol, Kabupaten Donggala sehingga hasil penelitian ini hanya dapat dijadikan bahan pertimbangan buat PEMDA Donggala sebagai model pendekatan dalam upaya peningkatan kapasitas potensi di pedesaan. Penelitian selanjutnya dapat melakukan generalisasi wilayah penelitian tentang peran LSPBM terhadap pembangunan ekonomi pedesaan khususnya di kabupaten-kabupaten yang ada di Provinsi Sulawesi Tengah sehingga dapat dijadikan dasar kebijakan pembangunan ekonomi pedesaan di Sulawesi Tengah. 
BISMA (Bisnis dan Manajemen)

Volume 11 Nomor 2, April 2019

E-ISSN 2549-7790, P-ISSN 1979-7192

Halaman 182-206

\section{REFERENSI}

ADB. (2000). Finance for the Poor: Microfinance Development Strategy. Manila. Asian Development Bank.

Akiyoshi and Komoda. (2005). An analysis framework of enterprise documents for business strategy design. International conference on intelligent agents, web technologies and internet commerce, vol. 1, IEEE (2005), pp. 65-69.

Arif, Aulia. (2014). Introduction Into Micro Finance. (http://auliaarif93.blogspot.com/2014/01/makalah-lembaga-keuangan-mikroimf.html). Diakses tanggal 29 Juli 2018.

Coman and Ronen. (2009). Focused SWOT: Diagnosing critical strengths and weaknesses International Journal of Production Research, 47 (2009), pp. 56775689 .

Ellis, Frank dan Stephen Biggs. (2001). Evolving Themes in Rural Development 1950s-2000s. Development Policy Review, Vol. 19, No. 4: 437-448.

Ghazinoory et al., (2011). SWOT methodology: A state-of-the-art review for the past, a framework for the future. Journal of Business Economics and Management, 12 (2011), pp. 24-48.

Helms, M.M. and Nixon J. (2010). Exploring SWOT analysis - where are we now?: A review of academic research from the last decade, Journal of Strategy and Management, Vol. 3(3), pp. 215- 251

Hermawan, Hari dan Andrianyta, Harmi. (2012). Lembaga Keuangan Mikro Agribisnis: Terobosan Penguatan Kelembagaan dan Pembiayaan Pertanian di Pedesaan. Jurnal Analis Kebijakan Pertanian Vol 10 No 2, Juni 2012: 143-158.

Kristi, Astrid Rahayu. (2009). Eksistensi Lembaga Keuangan Mikro dalam Pembagunan Ekonomi Pedesaan. Makalah Kolokium IPB. https://kolokiumkpmipb. wordpress.com/2009/04/22/eksistensi-lembagakeuangan-mikro-dalam-pembangunan-konomi-pedesaan/. Diakses pada tanggal 2 April.

Panagiotou, G. (2003). Bringing SWOT into focus. Business Strategy Review, Vol. 14(2), pp. 8-10.

Pantoro, Setyo. (2010). Pendekatan Pengembangan Lembaga Keuangan Mikro (LKM) dan Implikasinya. https://setyopantoro.wordpress.com. Diakses tanggal 27-2-2018.

Rahmana, Arief. (2018). Keragaman Definisi UMKM di Indonesia. https://infoUMKM.wordpress.com/2008/08/11. Diakses tanggal 29 Juli 2018. 
Nirmala Dewi, Moh. Arafa, Rika Suprapty Peran Lembaga Simpan Pinjam Berbasis Masyarakat (LSPBM) Usaha Bersama Desa Siboang terhadap Pembangunan Ekonomi Pedesaan

Rostirolla M. and Rostirolla P. (2011). A Multivariate and Multicriterial Approach for the SWOT Analysis, Journal of Applied Sciences, Vol 11 (4), pp. 719-724.

Sumodiningarat, Gunawan. (2015). Peranan Lembaga Keuangan Mikro dalam Menanggulangi Kemiskinan Terkait dengan Kebijakan Otonomi Daerah. Artikel Tahun II no. 1 Jurnal Ekonomi Pertanian. www.ekonomirakyat.go.id/co.id. Diakses tanggal 27-2-2018.

Syahyuti, (2008). Strategi dan Tantangan dalam Pengembangan Gabungan Petani (GAPOKTAN) Sebagai Kelembagaan Ekonomi di Pedesaan. Pusat Analisis Sosial Ekonomi dan Kebijakan Pertanian. Bogor. https://syahyuti.wordpress.com. Diakses tanggal 27-2-2018.

Yustika, Ahmad Erani. (2008). Ekonomi Kelembagaan: Definisi, Teori, dan Strategi. Bayumedia Publishing: Jakarta.

Undang-Undang No.20 Tahun 2008 
BISMA (Bisnis dan Manajemen)

Volume 11 Nomor 2, April 2019

E-ISSN 2549-7790, P-ISSN 1979-7192

Halaman 182-206

Lampiran. Matriks SWOT

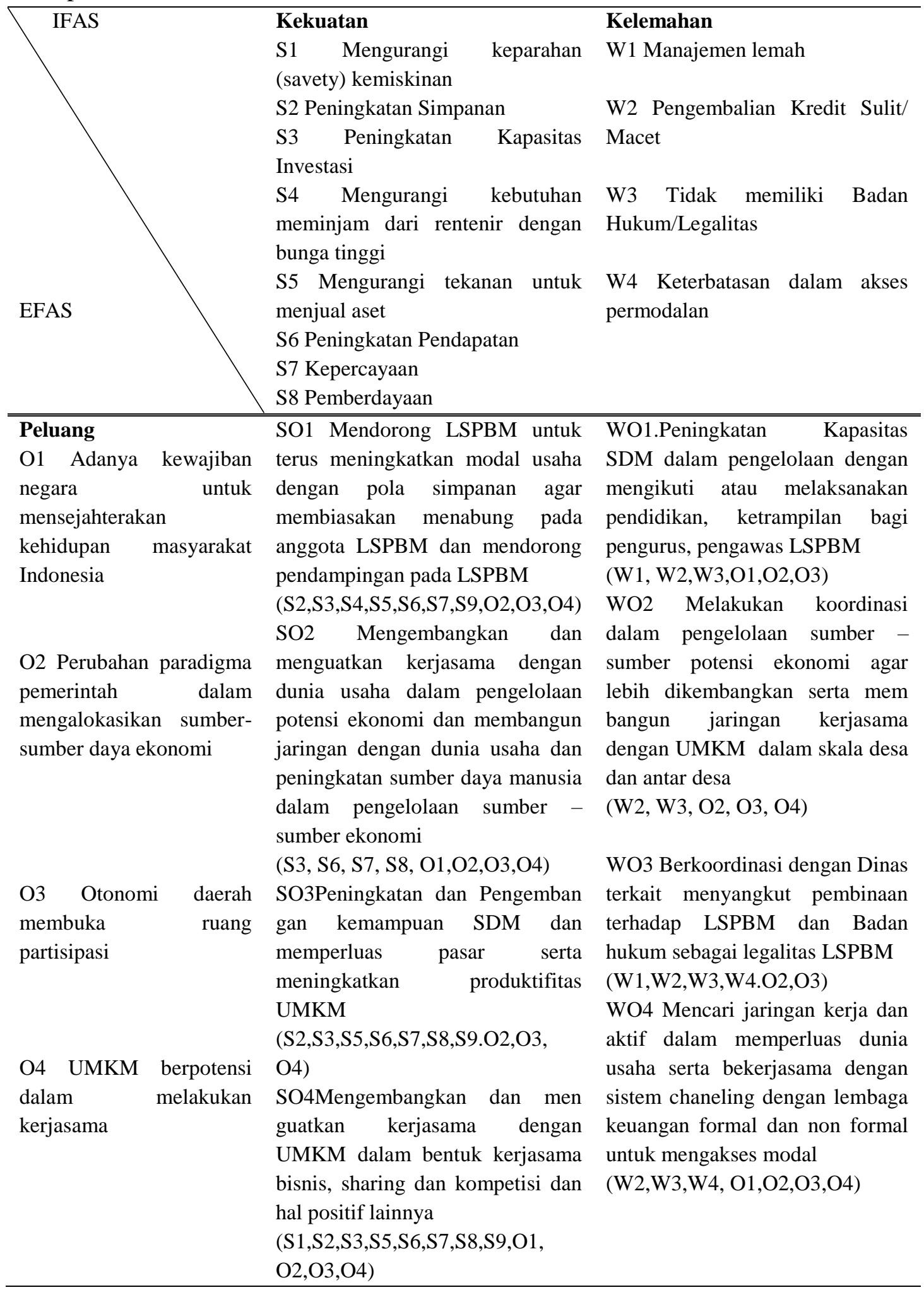


Nirmala Dewi, Moh. Arafa, Rika Suprapty Peran Lembaga Simpan Pinjam Berbasis Masyarakat (LSPBM) Usaha Bersama Desa Siboang terhadap Pembangunan Ekonomi Pedesaan

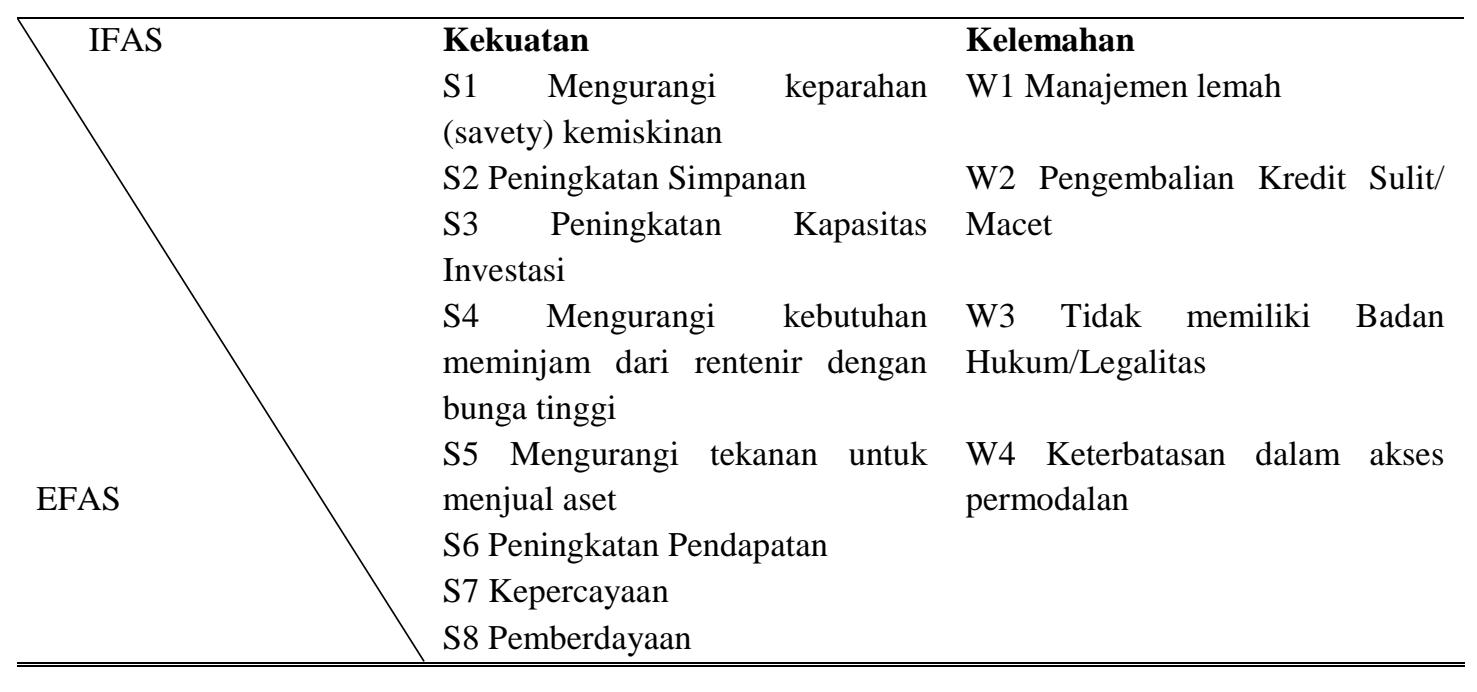

\section{Ancaman}

T1 Persyaratan teknis ST1 Memberikan pelatihan pada kurang dipenuhi

T2 Rendahnya Profesiona lisme kerja Pengurus LSPBM efektif

\section{UMKM dalam pembuatan} proposal serta persyaratan teknis dalam peningkatan usaha UMKM (S2,S3,S4,S5,S6,S7,S8,S9, T2,T3)

ST2Meningkatkan pola rekrutmen dalam pengurus untuk meningkatkan kapasitas dan bekerjsama dengan Dinas terkait dalam pembinaan (S3,S7,S8,S9, T1,T2,T3)

T3 Bantuan teknis kurang
ST3 Meningkatkan jaringan dan koordinasi dengan pemerintah dan swasta serta memperluas kerjasama UMKM

(S2,S3,S4,S6,S7,S8,S9, T1,T2,T3)
WT1 Meningkatkan mutu pengelola melalui pelatihan dan bimtek dan melakukan koordinasi dengan dinas terkait (W1, W2,W4,T1,T2,T3)

WT2. Memperkuat persyaratan teknis dalam prosedure peminjaman kredit kepada anggota dan UMKM dan menigkatkan kapasitas pengurus dalam pengelolaan serta perlunya penambahan staff kantor (W1,W2,W3,W4, T1,T2,T3)

WT3 Memperkuat struktur organisasi dan Identifikasi dalam mengelola usaha di desa Siboang dan melakukan peninjauan terhadap AD-ART (W1,W2,W3,W4,T1,T2,T3)

Sumber: data diolah 